Cite as: Alfaro-Gramajo, L. N., Pérez-Pineda, F., Quintanilla, C. \& Sanz, L. J. (2013). Are we really having an impact? A comprehensive approach to assessing improvements in critical thinking in an MBA program. Informing Science: the International Journal of an Emerging Transdiscipline, 16, 273-295. Retrieved from http://www.inform.nu/Articles/Vol16/ISJv16p273-295AlfaroCS07.pdf

SPECIAL SERIES: THE ROLE OF CASE STUDIES IN INFORMING SYSTEMS

\title{
Are We Really Having an Impact? A Comprehensive Approach to Assessing Improvements in Critical Thinking in an MBA Program
}

\author{
Luis Noel Alfaro-Gramajo, Felipe Pérez-Pineda, \\ and Carlos Quintanilla \\ INCAE Business School, Montefresco, Nicaragua
}

luis.alfaro@incae.edu felipe.perez@incae.edu carlos.quintanilla@incae.edu

Luis J. Sanz, INCAE Business School, Alajuela, Costa Rica luis.sanz@incae.edu

\begin{abstract}
Material published as part of this publication, either on-line or in print, is copyrighted by the Informing Science Institute. Permission to make digital or paper copy of part or all of these works for personal or classroom use is granted without fee provided that the copies are not made or distributed for profit or commercial advantage AND that copies 1) bear this notice in full and 2) give the full citation on the first page. It is permissible to abstract these works so long as credit is given. To copy in all other cases or to republish or to post on a server or to redistribute to lists requires specific permission and payment of a fee. Contact Publisher@InformingScience.org to request redistribution permission.
\end{abstract}

While executives and faculty recognize the importance of critical thinking skills for business graduates, it is often debated whether students come into MBA programs with these skills, and if not, whether such skills can be effectively taught. This paper describes our experience in measuring the improvement of critical thinking skills in the MBA program at a well-known Business School in Central America. Recognizing the intricate nature of the learning process using the case method, we proceeded to apply three different approaches to gauge its impact on student problem-solving ability: the application of standardized tests in critical thinking skills to incoming students and, later on, to those same students just before completing the program; a pre- postcomparison of written case analyses; and the use of the capstone "Management Consulting Practice" experience as a course-embedded assessment instrument to evaluate critical thinking skills in a real-world context. From this experience we concluded two things: first, the MBA program does have an impact, not only improving students' critical thinking skills, but also leveling the playing field in this area with respect to their U.S. counterparts. Second, assessing improvement in critical thinking skills is a complex task calling for a multi-measures approach, in particular if the intent is to develop corrective measures. When such an approach is applied, the quality of information for improvement is enhanced and a more complex informing network emerges, including faculty from diverse functional areas who do not

Keywords: Case method, learning assessment, critical thinking, MBA, Latin America. normally interact. 


\section{Introduction}

While executives and faculty recognize the importance of critical thinking skills for business graduates, according to Datar, Garvin, and Cullen (2010) it is often debated whether students come into the MBA program with these skills, and if not, whether they can be effectively taught. While several schools around the globe try to develop critical thinking skills through the use of student-centered teaching / learning methodologies, measuring the effects is often neglected due to the complexity and difficulty of the task. This article describes our experience in assessing the advancement of critical thinking skills at a well-known Central American business school and presents our findings on the impact of the case method in improving these skills.

But what do we mean by critical thinking? Definitions of critical thinking range from the general to the particular. Schoenberg (2007) defines critical thinking as a set of higher order thinking skills that include metacognition (thinking about thinking), frames of reference, and seeking evidence. Arons (1985) defines critical thinking as an approach that focuses on the thinking and reasoning processes that underlie analysis and inquiry. Facione (1990) looks at it as purposeful, self-regulatory judgment which results in interpretation, analysis, evaluation, and inference, as well as explanation of the evidential, conceptual, methodological, criteriological, or contextual considerations upon which that judgment is based.

Similarly, Paul (1990) begins from a general statement (thinking that displays mastery of intellectual skills and abilities) but moves to the particular in stating that it exemplifies the perfections of thinking appropriate to a particular mode or domain of thinking. Fisher and Scriven (1997) expand the definition to include communications, information, and argumentation. Nickerson, Perkins, and Smith (1985) develop the concept further by saying that critical thinking is the ability to judge the plausibility of specific assertions, to weigh evidence, to assess the logical soundness of inferences, to construct counter-arguments and alternative hypotheses. In order to do so, Paul and Elder (2005) identify eight essential elements underpinning critical thinking: purpose, questions, points of view, information, assumptions, concepts, conclusions, and consequences. Finally, Ennis (2002) focuses critical thinking on decision making by relating it to action: it is reasonable, reflective thinking that is intended on deciding what to do or believe.

Due to the practical nature of business skills, we follow Ennis when we state that one of the academic objectives of our masters' programs is for the graduates to possess an attitude toward action, characterized by the ability to recognize problems and conflicts that occur in organizations, a sense of critical judgment, capability to make firm decisions, and talent to convert their decisions into action programs consistent with the particular situation of their organization. Hence, when we try to foster critical thinking skills, we focus on critical thinking for action.

From an informing systems perspective, this means that the case is used as an instrument not only to open flows of information to sharpen students' skills in decision analysis but also to understand and improve their decision making process. While the complexity of management decisions makes them difficult to replicate, learning from one's own experience is a very important skill for managers in current (volatile) times, since managerial decisions usually need to be made without the scientific luxury of previously testing one's hypotheses, and executives can only hope to refine their abilities so they can perform better next time.

Several studies have attempted to measure the development of critical thinking skills in business students. Garvey and Buckley (2011) look at the use of technology on the teaching of risk management to improve critical thinking on this subject. They propose an innovative application of prediction market technology within business education as a method that can be used to encourage students to think about risk in an open and flexible way. The article explains how prediction markets also provide students with the necessary experience to critically evaluate and stress-test 
quantitative risk modeling techniques later in their academic and professional careers. McLellan (2012) found that standardized tests can be used to measure the critical thinking skills of accounting students in Abu Dhabi. Williams and Lhama (2009) analyze online forums and conclude that online discussion promotes student engagement and the development of critical thinking skills. Pomonis and Siriopoulos (2009) study how students' learning strategies have an impact on the acquisition and improvement of critical thinking skills when teaching financial management at the University of Patras, Greece. In order to do so the study used Kolb's Learning Style Inventory together with the California Critical Thinking Skills Tests three times: two months before the beginning of the course, just before the beginning of the course, and after the final exam.

With the exception of Williams and Lhama (2009), all these studies focus on measuring the improving of critical thinking skills in one particular subject area, and these authors restrict themselves to one aspect of the learning process. Following Paul (1990), they confine themselves to a specific context. And while from the previous definitions, critical thinking seems to involve a very complex set of skills that include analysis, deduction, inference, evaluation, and induction, all authors except Pomonis and Siriopoulos used only one method to assess critical thinking.

We contribute to this discussion by departing from these studies in two dimensions. First, we look at the development of critical skills, not within the realm of one specific subject area, but as part of the achievements of a two year full time MBA program. We used similar standardized tests because we argue that they are better suited to analyze critical thinking at the program level than at the level of individual subjects (which must be more specific in nature in order to include the logic underpinning the subject). Second, we did not confine ourselves to these instruments. We also applied formative and summative tests on critical thinking skills applied to the written analyses of cases. We also used the capstone "Management Consulting Practice" experience as a course-embedded assessment instrument that evaluates critical thinking skills for action in order to refine our conclusions from the previous measures.

From this multi-measures approach we reached two conclusions: first, our MBA program, which is grounded in participant-centered learning methods, does have an impact not only on improving students' critical thinking skills, but also on leveling the playing field with their counterparts who studied as undergraduates in United States universities. Second, we found that by using multiple measures to assess improvement in critical thinking skills, it is possible to be much more precise in identifying students' weaknesses and to prescribe corrective action.

The remainder of the paper is organized as follows: the next three sections describe each of the three instruments that we applied and the results that were obtained. The final section discusses our findings and offers some concluding remarks.

\section{First Approach: Standardized Tests of Skills and Dispositions Generally Associated with Critical Thinking}

We chose two standardized tests offered by Insight Assessments: the California Critical Thinking Skills Tests (CCTST) and the California Critical Thinking Disposition Inventory Test (CCTDI). These tests, based on the consensus of Critical Thinking presented in Facione (1990), measure two dimensions of critical thinking: skills and dispositions.

The CCTST is made of 34 multiple-choice questions ranging in difficulty and complexity which, according to Facione (1990), "broadly represent reasoning ability required to succeed in those educational and workplace settings in thoughtfully forming a judgment regarding what to believe or what to do is a prerequisite." Critical thinking skills are measured on five different scales, defined by Facione (1990) as follows: 
- Analysis: Analytical reasoning skills enable people to identify assumptions, reasons, and claims and to examine how they interact in the formation of arguments. We use analysis to gather information from charts, graphs, diagrams, spoken language, and documents. People with strong analytical skills attend to patterns and to details. They identify the elements of a situation and determine how those parts interact. Strong interpretation skills can support high quality analysis by providing insights into the significance of what a person is saying or what something means.

- Inference: Inference skills enable us to draw conclusions from reasons and evidence. We use inference when we offer thoughtful suggestions and hypotheses. Inference skills indicate the necessary or the very probable consequences of a given set of facts and conditions. Conclusions, hypotheses, recommendations, or decisions that are based on faulty analyses, misinformation, bad data, or biased evaluations can turn out to be mistaken, even if they have been reached using excellent inference skills.

- Evaluation: Evaluative reasoning skills enable us to assess the credibility of sources of information and the claims they make. And, we use these skills to determine the strength or weakness of arguments. Applying evaluation skills we can judge the quality of analyses, interpretations, explanations, inferences, options, opinions, beliefs, ideas, proposals, and decisions. Strong explanation skills can support high quality evaluation by providing the evidence, reasons, methods, criteria, or assumptions behind the claims made and the conclusions reached.

- Deduction: Decision making in precisely defined contexts where rules, operating conditions, core beliefs, values, policies, principles, procedures, and terminology completely determine the outcome depends on strong deductive reasoning skills. Deductive reasoning moves with exacting precision from the assumed truth of a set of beliefs to a conclusion which cannot be false if those beliefs are true. Deductive validity is rigorously logical and clear-cut. Deductive validity leaves no room for uncertainty, unless one alters the meanings of words or the grammar of the language.

- Induction: Decision making in contexts of uncertainty relies on inductive reasoning. We use inductive reasoning skills when we draw inferences about what we think must probably be true based on analogies, case studies, prior experience, statistical analyses, simulations, hypotheticals, and familiar circumstances and patterns of behavior. As long as there is the possibility, however remote, that a highly probable conclusion might be mistaken, the reasoning is inductive. Although it does not yield certainty, inductive reasoning can provide a solid basis for confidence in our conclusions.

The second test, the CCTDI, measures the dispositional dimension, i.e., the willingness to put one's critical thinking skills into action. The respondents of the tests are asked to express agreement or disagreement with 75 statements expressing "beliefs, values, attitudes, and intentions that relate to the reflective formation of reasoned judgments" Facione (1990). The tests are scored on seven different scales, defined by Facione as follows:

- Truth-seeking Scale: It is the habit of always desiring the best possible understanding of any given situation; it is following reasons and evidence where ever they may lead, even if they lead one to question cherished beliefs. Truth-seekers ask hard, sometimes even frightening questions; they do not ignore relevant details; they strive not to let bias or preconception color their search for knowledge and truth. The opposite of truth-seeking is bias which ignores good reasons and relevant evidence in order not to have to face difficult ideas.

- Open-mindedness Scale: It is the tendency to allow others to voice views with which one may not agree. Open-minded people act with tolerance toward the opinions of others, 
knowing that often we all hold beliefs which make sense only from our own perspectives. Open-mindedness, as used here, is important for harmony in a pluralistic and complex society where people approach issues from different religious, political, social, family, cultural, and personal backgrounds. The opposite of open-mindedness is closedmindedness and intolerance for the ideas of others.

- Analyticity Scale: It is the tendency to be alert to what happens next. This is the habit of striving to anticipate both the good and the bad potential consequences or outcomes of situations, choices, proposals, and plans. The opposite of analyticity is being heedless of consequences, not attending to what happens next when one makes choices or accepts ideas uncritically.

- Systematicity Scale: It is the tendency or habit of striving to approach problems in a disciplined, orderly, and systematic way. The habit of being disorganized is the opposite characteristic to systematicity. The person who is strong in systematicity may or may not actually know or use a given strategy or any particular pattern in problem solving, but he or she has the mental desire and tendency to approach questions and issues in such an organized way.

- Critical Thinking Self-Confidence Scale: It is the tendency to trust the use of reason and reflective thinking to solve problems. This habit can apply to individuals or to groups as can the other dispositional characteristics measured by the CCTDI. We as a family, team, office, community, or society can have the habit of being trustful of reasoned judgment as the means of solving our problems and reaching our goals. The opposite is the tendency to be mistrustful of reason, to consistently devalue or be hostile to the use of careful reason and reflection as a means to solving problems or discovering what to do or what to believe.

- Inquisitiveness Scale: It is intellectual curiosity. It is the tendency to want to know things, even if they are not immediately or obviously useful. It is being curious and eager to acquire new knowledge and to learn the explanations for things even when the applications of that new learning are not immediately apparent. The opposite of inquisitiveness is indifference.

Insightful Assessment, the company that sells these tests, reports that their validity derives from the "cross disciplinary conceptual definition of critical thinking that emerged from the APA Delphi Research Study (1988-1990) and was replicated by the Department of Education [of the U.S.] supported Penn State University Research Study". Indices of consistency (reliability) are also reported. The company's webpage (http://www.insightassessment.com) also reports that "the internal consistency statistic for these skill tests is the KR-20 coefficient (...). Reliability coefficients range between $0.77-0.83$, extremely high for a measurement of an attribute as complex as critical thinking."

Both tests were administered to the same group of students at two points in time: three months after they joined the MBA program and on the last day of class. The first test was used as our measure of before-the-program performance; the second was our measure of after-the-program performance. As an additional measure of the effect of our program, we compared the scores of our students with the scores of two groups of students in the United States: 4-year college graduates and graduate students.

Table 1 presents descriptive statistics for the five components of the CCTST as well as for the total score. The upper panel reports these results for the first test taken in 2009 (with 61 students); the lower panel does the same for the second test taken a year later (with -52 students). In all categories, with the exception of "Evaluation", the results show increases in the average scores on the second test, indicating a positive effect of the MBA, and in particular of the case method- 
ology, on the critical thinking skills of our students. In the last row of the table, we report the pvalue associated with the standard t-statistic for difference of means (assuming different variances in the population). The null hypothesis was that "MBA program has not improved these scores". Hence the null is rejected in favor of the alternative hypothesis ("Positive Effect of the program") at any standard level of significance for all categories with the exception of "Evaluation" and "Deduction", which appear to be statistically the same before and after the program.

Table 1: Results, CCTST Exam

\begin{tabular}{|c|c|c|c|c|c|c|c|}
\hline & & Induction & Deduction & Analysis & Inference & Evaluation & Total \\
\hline \multirow[t]{4}{*}{ First Test } & Mean & 4.92 & 7.57 & 3.82 & 6.20 & 4.05 & 14.17 \\
\hline & St. Deviation & 2.27 & 2.06 & 1.42 & 1.56 & 2.30 & 3.02 \\
\hline & St. Error Mean & 0.29 & 0.26 & 0.18 & 0.20 & 0.29 & 0.39 \\
\hline & Nobs & 61 & 61 & 61 & 61 & 61 & 61 \\
\hline \multirow[t]{5}{*}{ Second Test } & Mean & 8.79 & 7.79 & 4.63 & 8.06 & 3.88 & 16.58 \\
\hline & St. Deviation & 2.25 & 2.30 & 1.39 & 2.18 & 1.65 & 3.81 \\
\hline & St. Error Mean & 0.31 & 0.32 & 0.19 & 0.30 & 0.23 & 0.53 \\
\hline & Nobs & 52 & 52 & 52 & 52 & 52 & 52 \\
\hline & P-Value & 0.000000 & 0.325526 & 0.001884 & 0.000001 & 0.298770 & 0.000197 \\
\hline
\end{tabular}

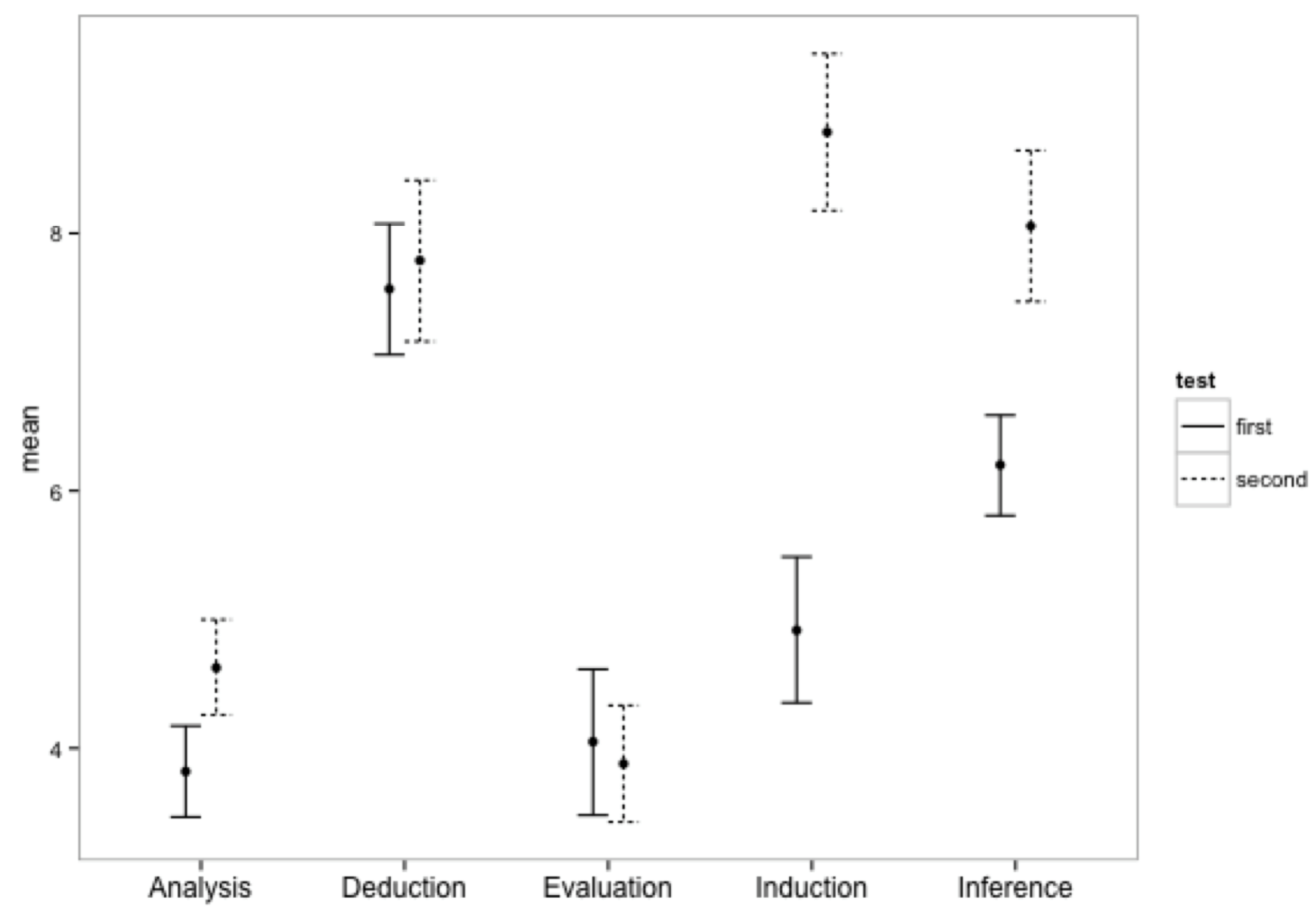

Figure 1: Comparison CCTST Scores Before and After MBA

Figure 1 shows the results graphically. Each column represents a component of the CCTST. The average scores for each group (before and after the MBA) are represented by dots of different colors. Two standard errors are added and subtracted to each mean to form a traditional confidence interval for the mean, represented by vertical colored lines. These graphs can be used to determine which components improved significantly, although they are not entirely equivalent to 
the formal tests. The intervals for categories "Analysis", "Induction" and "Inference" show no overlap confirming the rejection of the null. The same is true for the Total Score (not shown in the graph). The intervals for categories "Evaluation" and "Deduction" do show some significant overlap. No significant effect was detected for them.

Insight Assessments publishes aggregate statistics for the results of the CCTST for U.S. universities at the undergraduate and graduate levels. We used these results as a benchmark against which we could compare the results for our students. No data averages were published, but we had median scores. In Figure 2 we compare, for each of the five scales, the performance of four groups: (our) MBA students before and after the program, U.S. 4-year college graduates, and U.S. graduate students. With the exception of "Deduction", entering MBA students score the same or lower than 4-year U.S. college graduates. As expected, U.S. graduate students score the same or higher than the 4-year college graduates.

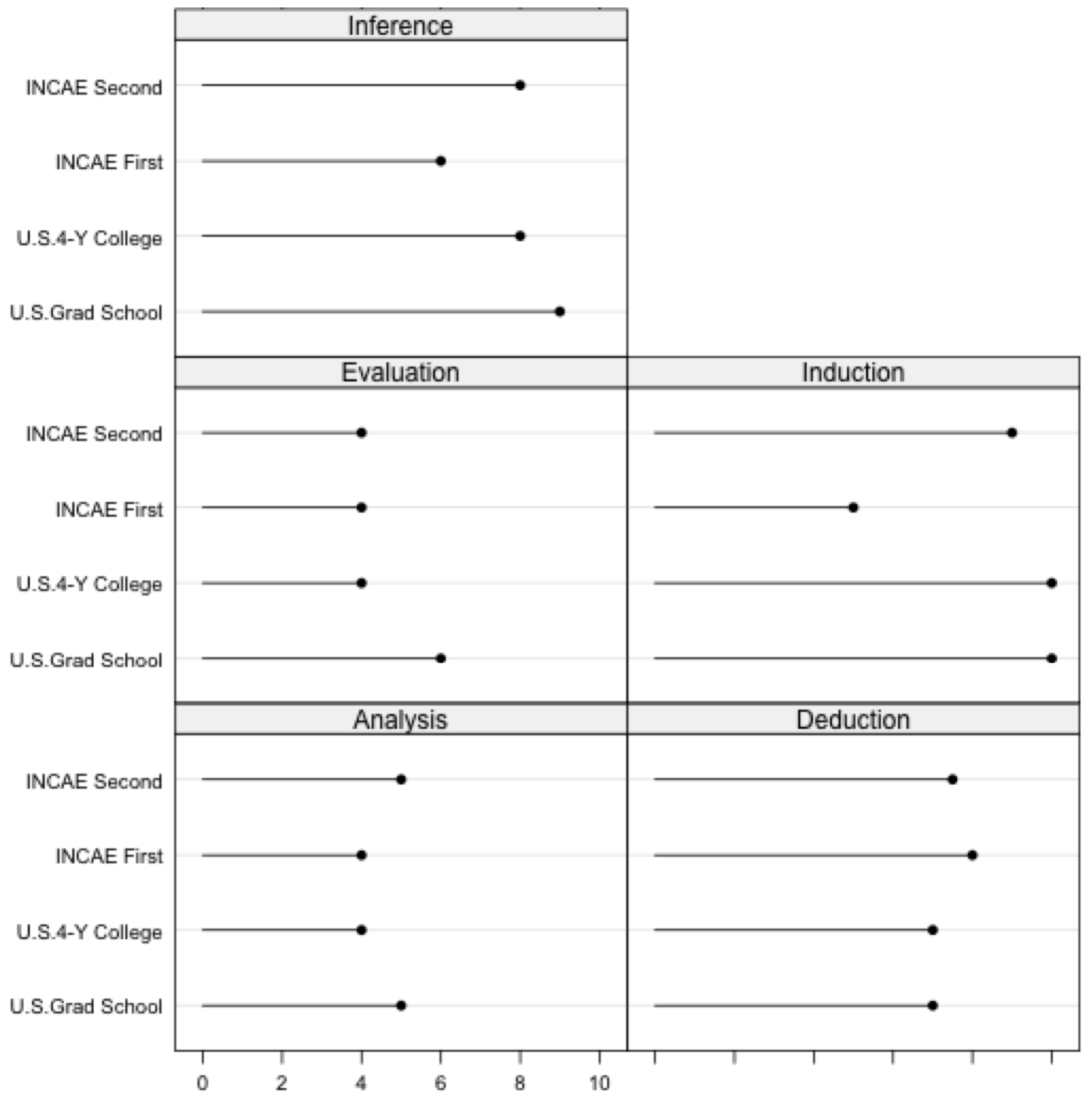

Figure 2: Comparison CCTST Median Scores INCAE students before and after the MBA Program and US Benchmarks 
This finding suggests that the critical thinking skills of Latin American university graduates are less developed than that of their U.S. counterparts. By the time our students graduate, they meet or surpass U.S. 4-year college graduates in all critical thinking categories except "Induction", and in this category the gap is significantly reduced. This progress is remarkable since this was the lowest-scoring category when they entered the school. It is, however, the category where we would expect to see the greatest improvement given the teaching methodology. Finally, in the case of "Analysis" we even manage to close the gap with respect to U.S. post-graduates.

Now we review the results of the California Critical Thinking Dispositions Inventory (CCTDI). Table 2 reports statistics for each component measured by this test. The upper panel reports the results for the 63 students who took that test shortly after entering the program; the lower panel reports the results for the 52 students who took the on the last day of class. While the CCTST results showed a noticeable improvement in almost all categories, the results are quite different for the CCTDI: the evidence in favor an improvement is weak at best.

Table 2: Results CCTDI

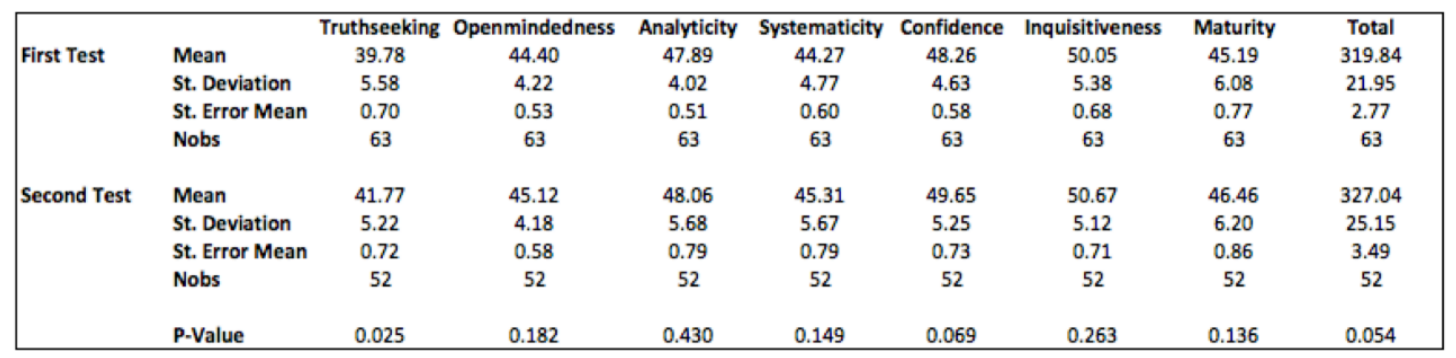

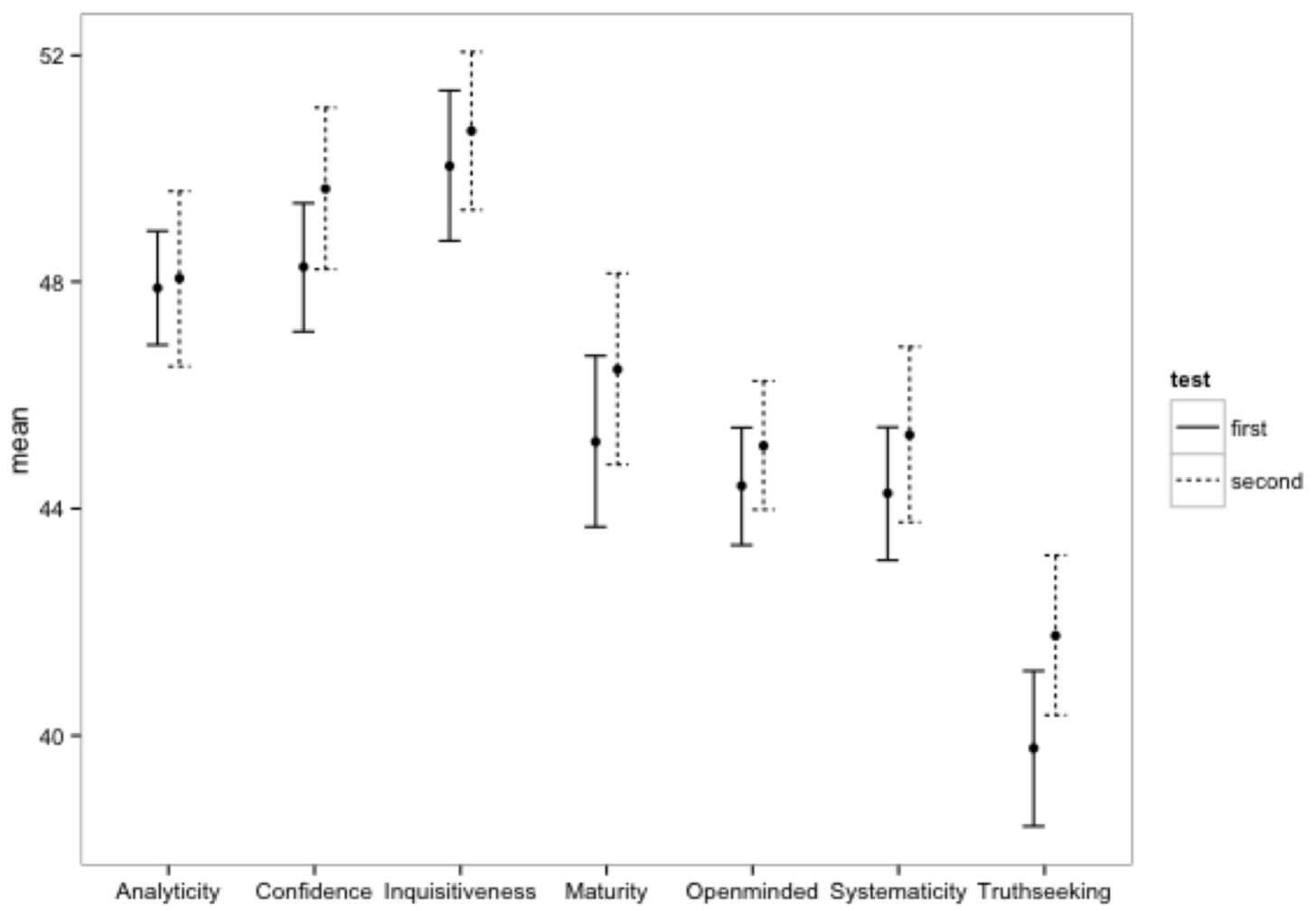

Figure 3: Comparison CCTDI Scores Before and After MBA 
With the sole exception of the component "Truth-seeking", we do not observe any significant changes in student behavior. The last row of Table 2 reports p-values associated with the null hypothesis that "the program has not had any positive effect on the students' values as measured by this test". All p-values, except the one corresponding to "Truth-seeking", are above the standard 5\%. "Confidence" and the total score also show mild improvements which are significant at the $10 \%$ significance level. Figure 3 repeats the analysis graphically. The general impression of no change is confirmed by the overlapping of confidence intervals in all components of the CCTDI.

At first reading, these results are somewhat discouraging; they suggest that our MBA program has had no impact on the values and attitudes that are most important to the application of develop critical thinking skills. However, when compared with the results of studies of critical skills dispositions in economics programs (Bauman \& Rose, 2009; Frank \& Schulze, 2000), the results are less discouraging.

\section{Pre- and Post- Written Case Analysis}

Our second approach to measure the impact of our MBA program in students' critical thinking skills was to compare a sample of written case analyses at the beginning and toward the end of the MBA program. "Managerial Decisions," a required course offered during the first eight weeks of class, was the logical choice of a course in which to embed this instrument for the initial measure. Based on the "Written Analysis of Cases" course at the Harvard Business School, it is the course most directly related to the development of critical thinking skills.

For the post-test we used a written case analysis given as the final exam of "Managerial Processes," a course on strategy implementation offered in the final semester of the second year. Though not required, between 80 and 90 percent of the second-year students choose to enroll. To make the pre- and post-tests comparable, an equal amount of time was allowed for both. In both tests students were given instructions, but in the pre-test these were highly structured in accordance with the Managerial Decisions framework (define the problem, determine objectives, identify and analyze alternatives) whereas in the post-test students were simply asked to present their analysis and recommendations.

The cases used differed in complexity. For the pre-test, the case was on the decision to export a traditional Peruvian beverage to Venezuela and, if so, whether in bulk or bottled. The case for the post-test involved the implementation of an expansion plan that required decisions on the structure and staffing of manufacturing plants in two Central American countries. However, the analytical skills required to solve each problem were the same in both cases.

The sample used was approximately one-third of the selected class. Students in that class were asked to submit ungraded copies of their first written case analysis (the course professor maintains only graded copies) and the first twenty to be received were selected. The profile of the sample reflected that of the entire class: $63 \%$ male and 37\% female; $74 \%$ from Central America and $26 \%$ from other regions, principally South America.

Nineteen pairs of usable pre- and post- written case analyses were evaluated by two professors from the MD and Managerial Processes courses. They began by developing a rubric and applying it to a pilot (blind) evaluation of the pre- and post- papers of three students (see Table 3). They met to analyze and discuss the results. Surprisingly, they found that the pre-tests were more structured and coherent than the post-tests. This could be attributed, at least in part, to the differing complexity of the cases and to the highly structured guidelines that were provided for the pre-test, versus the open-ended nature of the questions posed in the post-test. 
Table 3: Rubric for WAC

\begin{tabular}{|c|c|c|c|c|}
\hline $\begin{array}{c}\text { Critical thinking } \\
\text { skill }\end{array}$ & $\begin{array}{c}\text { Level 0: Very } \\
\text { weak }\end{array}$ & $\begin{array}{l}\text { Level 1: Par- } \\
\text { tially devel- } \\
\text { oped }\end{array}$ & $\begin{array}{l}\text { Level 2: Sub- } \\
\text { stantially } \\
\text { developed }\end{array}$ & $\begin{array}{c}\text { Levels } 3 \text { / 4: Excel- } \\
\text { lent }\end{array}$ \\
\hline $\begin{array}{l}\text { Identifies problems } \\
\text { and causes, interre- } \\
\text { lations among } \\
\text { problems, and pri- } \\
\text { orities facing the } \\
\text { decision-maker }\end{array}$ & $\begin{array}{l}\text { States problems } \\
\text { without identi- } \\
\text { fying causes or } \\
\text { explaining } \\
\text { relevance }\end{array}$ & $\begin{array}{l}\text { Identifies most } \\
\text { evident prob- } \\
\text { lems and } \\
\text { causes, and } \\
\text { explains rele- } \\
\text { vance to key } \\
\text { issues }\end{array}$ & $\begin{array}{l}\text { Identifies } \\
\text { main and sub- } \\
\text { sidiary prob- } \\
\text { lems and their } \\
\text { relationships }\end{array}$ & $\begin{array}{l}\text { Level } 2+\text { identifying } \\
\text { priorities and most } \\
\text { important aspects of } \\
\text { problems }\end{array}$ \\
\hline $\begin{array}{l}\text { Understands the } \\
\text { perspective, objec- } \\
\text { tives, and assump- } \\
\text { tions of the deci- } \\
\text { sion-maker as well } \\
\text { as those of other } \\
\text { key actors }\end{array}$ & $\begin{array}{l}\text { Accepts point } \\
\text { of view of deci- } \\
\text { sion-maker; } \\
\text { does not ac- } \\
\text { knowledge } \\
\text { existence of } \\
\text { multiple per- } \\
\text { spectives }\end{array}$ & $\begin{array}{l}\text { Acknowledges } \\
\text { existence of } \\
\text { multiple per- } \\
\text { spectives but } \\
\text { focuses on } \\
\text { single perspec- } \\
\text { tive }\end{array}$ & $\begin{array}{l}\text { Acknowledges } \\
\text { existence of } \\
\text { multiple per- } \\
\text { spectives and } \\
\text { assumptions }\end{array}$ & $\begin{array}{l}\text { Level } 2+\text { evaluation } \\
\text { of salient perspectives } \\
\text { and critical assump- } \\
\text { tions }\end{array}$ \\
\hline $\begin{array}{l}\text { Identifies and con- } \\
\text { siders the influence } \\
\text { of the economic, } \\
\text { political, techno- } \\
\text { logical, cultural, } \\
\text { and ethical context } \\
\text { on issues }\end{array}$ & $\begin{array}{l}\text { Does not ad- } \\
\text { dress context }\end{array}$ & $\begin{array}{l}\text { Mentions con- } \\
\text { texts but does } \\
\text { not connect } \\
\text { them to the } \\
\text { problems iden- } \\
\text { tified }\end{array}$ & $\begin{array}{l}\text { Identifies and } \\
\text { considers the } \\
\text { influence of } \\
\text { context when } \\
\text { analyzing } \\
\text { perspectives }\end{array}$ & $\begin{array}{l}\text { Level } 2+\text { evaluation } \\
\text { of possible changes in } \\
\text { context in future (dif- } \\
\text { ferent future scenar- } \\
\text { ios) }\end{array}$ \\
\hline $\begin{array}{l}\text { Identifies and } \\
\text { evaluates the rea- } \\
\text { sonable alterna- } \\
\text { tives, their implica- } \\
\text { tions and conse- } \\
\text { quences using ob- } \\
\text { jective criteria }\end{array}$ & $\begin{array}{l}\text { Jumps to } \\
\text { "right" conclu- } \\
\text { sion without } \\
\text { considering } \\
\text { alternatives }\end{array}$ & $\begin{array}{l}\text { States alterna- } \\
\text { tives but sup- } \\
\text { ports preferred } \\
\text { alter-native } \\
\text { with only su- } \\
\text { perficial sup- } \\
\text { port to others }\end{array}$ & $\begin{array}{l}\text { Analyzes al- } \\
\text { ternatives, } \\
\text { their implica- } \\
\text { tions and con- } \\
\text { sequences } \\
\text { using objec- } \\
\text { tive criteria } \\
\end{array}$ & $\begin{array}{l}\text { Level } 2+\text { incorpora- } \\
\text { tion of problem } \\
\text { statement, perspec- } \\
\text { tives and context to } \\
\text { support conclusions }\end{array}$ \\
\hline $\begin{array}{l}\text { Makes effective } \\
\text { use of evidence; } \\
\text { assesses the quality } \\
\text { of that evidence in } \\
\text { problem identifica- } \\
\text { tion and in the } \\
\text { evaluation of alter- } \\
\text { natives }\end{array}$ & $\begin{array}{l}\text { Merely repeats } \\
\text { information } \\
\text { with no inter- } \\
\text { pretation }\end{array}$ & $\begin{array}{l}\text { Identifies evi- } \\
\text { dence that } \\
\text { tends to sup- } \\
\text { port own con- } \\
\text { clusion }\end{array}$ & $\begin{array}{l}\text { Distinguishes } \\
\text { be-teen opin- } \\
\text { ions, facts, } \\
\text { and infer- } \\
\text { ences. Ques- } \\
\text { tions quality } \\
\text { of evidence. }\end{array}$ & $\begin{array}{l}\text { Ranks evidence in } \\
\text { terms of importance, } \\
\text { relevance, reliability; } \\
\text { identifies missing data } \\
\text { and how to obtain } \\
\text { these data }\end{array}$ \\
\hline $\begin{array}{l}\text { Communicates the } \\
\text { conclusions of her } \\
\text { analysis and a real- } \\
\text { istic action plan }\end{array}$ & $\begin{array}{l}\text { Conclusion is } \\
\text { unconvincing } \\
\text { and no action } \\
\text { plan is pro- } \\
\text { vided }\end{array}$ & $\begin{array}{l}\text { Conclusion is } \\
\text { reason-able } \\
\text { but action plan } \\
\text { is unrealistic } \\
\text { or contains } \\
\text { unquestioned } \\
\text { assumptions }\end{array}$ & $\begin{array}{l}\text { Presents con- } \\
\text { vincing con- } \\
\text { clusion and a } \\
\text { realistic action } \\
\text { plan }\end{array}$ & $\begin{array}{l}\text { Level } 2 \\
\text { +recommendations } \\
\text { and action plan that } \\
\text { provides for continu- } \\
\text { ous improvement over } \\
\text { time }\end{array}$ \\
\hline
\end{tabular}


The pilot was essential in establishing uniform criteria. In the faculty discussion that followed, several reasons for the divergent scores were uncovered and resolved. For example, in the MD course, the "context" refers to both external (environmental) and internal (organizational) forces that influence a decision-maker; whereas in the Managerial Processes course, "context" is understood to mean the business environment that surround the company. These clarifications helped ensure greater consistency between professors in the evaluations.

The two professors then proceeded to evaluate the 16 remaining pairs of papers. The mean of the total 19 pre-test observations was 12.93, compared with a mean of 10.63 for the 19 post-test observations, a decrease of $18 \%$. The relative changes in four of the six evaluation criteria in the rubric (problem, objectives, context, and alternatives) were negative. Of the two remaining items, "action plan" showed improvement and "use of evidence" showed no statistically significant change (see Figure 4 and Table 4).

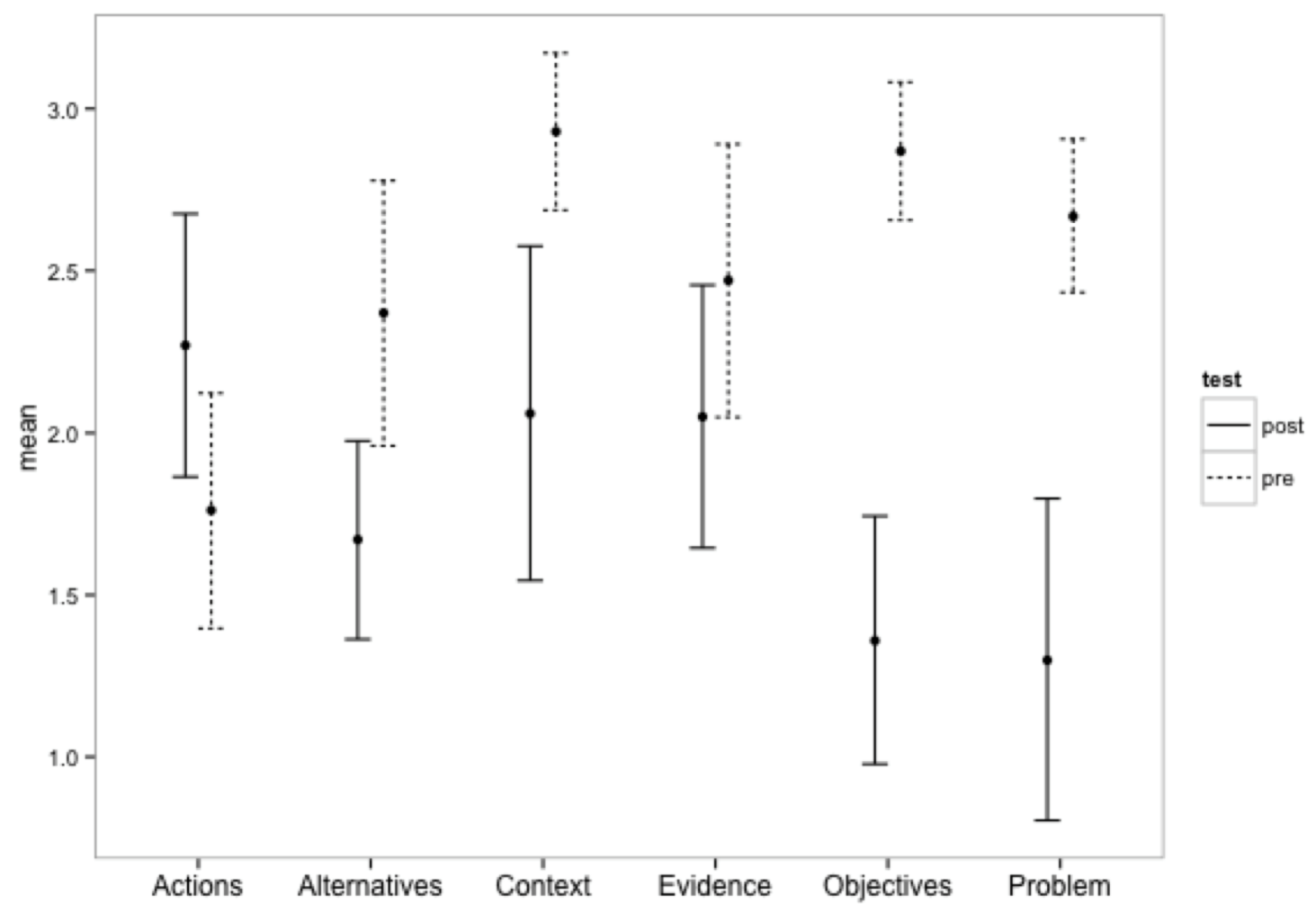

Figure 4: Comparison Pre-WAC and Post-WAC

These results confirm the findings of the pilot, in that entering students identified the problem, the objectives, and the alternatives available to the decision-maker in a more structured and coherent fashion, which we have attributed (at least in part) to the highly structured guidelines provided to the entering students versus the open-ended nature of the questions given to the same students shortly before graduation.

Notwithstanding this difference in the specificity of the instructions, the professors concluded that greater emphasis must be given to the analysis of problems and their causes in complex decision situations, not only in the MD course but in case discussions in all functional areas of the program. It is also important for students to understand the objectives, frequently conflicting, that the decision-maker seeks to achieve, as well as the perspectives and interests of other key players in the situation. Graduating students seemed to take these for granted and to go straight to the action questions rather than questioning their assumptions about the underlying causes of prob- 
lems or examining peoples' motives. Nonetheless, graduating students are better able to articulate their conclusions and recommendations and to link these with specific action steps for implementation.

Table 4: Pre vs. Post-WAC on Critical Thinking Skills

\begin{tabular}{|l|c|c|c|c|}
\hline Critical thinking skill & Pre-WAC & Post-WAC & Difference & P-Value \\
\hline $\begin{array}{l}\text { Identifies problems and causes, interrelations } \\
\text { among problems, and priorities facing the } \\
\text { decision-maker }\end{array}$ & 2.34 & 1.39 & $-40.4 \%$ & 0.0012 \\
\hline $\begin{array}{l}\text { Understands the perspective, objectives, and } \\
\text { assumptions of the decision-maker as well as } \\
\text { those of other key actors }\end{array}$ & 2.26 & 1.16 & $-48.7 \%$ & $<0.0001$ \\
\hline $\begin{array}{l}\text { Identifies and considers the influence of the } \\
\text { economic, political, technological, cultural, } \\
\text { and ethical context on the issues }\end{array}$ & 2.52 & 2.07 & $-17.9 \%$ & 0.0876 \\
\hline $\begin{array}{l}\text { Identifies and evaluates the reasonable alter- } \\
\text { natives, their implications and consequences } \\
\text { using objective criteria }\end{array}$ & 2.11 & 1.86 & $-11.7 \%$ & 0.2479 \\
\hline $\begin{array}{l}\text { Makes effective use of evidence; assesses the } \\
\text { quality of that evidence in problem identifica- } \\
\text { tion and in the evaluation of alternatives }\end{array}$ & 1.99 & 1.99 & $0.0 \%$ & 1.00 \\
\hline $\begin{array}{l}\text { Communicates the conclusions of her analy- } \\
\text { sis and a realistic action plan }\end{array}$ & 1.70 & 2.15 & $26.4 \%$ & 0.0684 \\
\hline Score Total & 12.93 & 10.63 & $-17.8 \%$ & 0.0065 \\
\hline
\end{tabular}

There was little difference between the pre- and post- scores regarding "context." Since there was little information provided in the cases about the environmental context in which the decisions were being made and therefore little to distinguish one student's performance from another's, the professors concluded that this area required more data and new tests. With respect to "alternatives," graduating students performed at a slightly lower level, perhaps due to the greater complexity of the case used in the post-test. However, it is worth noting that very few entering students considered alternatives that were not clearly stated in the case.

The general conclusions drawn by the faculty from the first assessment of the pre- and postwritten case analyses are then, the following:

1. The MBA program does build students' abilities in communicating action plans in support of their decisions, but there is much room for improvement. This could be done by increasing the number of written assignments, where students must go beyond the analysis of alternatives to consider the ways in which they will implement their decisions.

2. Though students learn early on to define problems, they may later on acquire the habit of neglecting this important step in the decision process.

3. The case method may have the unintended result of reinforcing a unitary decision-maker paradigm that does not reflect how decisions are made in the real world.

\section{Third Approach: Capstone Assessment}

Our third and final approach to assess the improvement of critical thinking in our MBA program was to use the capstone experience, Management Consulting Practice (MCP). The experience begins with the formation of 4-5 person teams that search for a client company during the latter part of the first year and the vacation period, followed by participation in an introductory half- 
course on "Consulting", which is conducted at the beginning of the second year (The following description is based on Ickis et. al., 2009). During this course, the student teams develop proposals that are submitted to the MCP faculty by the end of the third week of class. These proposals are reviewed by the MCP faculty and are returned to the students with feedback during the following week. They must then submit a revised proposal, including a detailed work plan, by the end of the sixth week of class, and a signed letter of agreement with their client, including a detailed budget, at the end of the seventh week.

During the eight weeks in the field, students work full-time in the client company, interacting with executives to solve a real-world business problem of a strategic nature. They receive at least two one-day visits from their assigned faculty advisor, who also provides continuous feedback on progress and makes comments on drafts. On the first day of class in January, the student teams submit a written report, and over the following two weeks, each team makes a 45-minute presentation to a panel of at least three MCP faculty plus invited executives from the client company, followed by a question-and-answer session of one hour fifteen minutes.

For grading purposes, the MCP faculty evaluates the students according to eleven criteria for the report and five criteria for the presentation (see the rubric in the Appendix). Grades of Pass, Fail, and High Pass (awarded to $25 \%$ to $30 \%$ of the groups) are assigned but not averaged in the GPA. However, a Fail is indeed equivalent to three grades of "C", and no more than five C's are allowed during the second year. The assessment considers also whether the student work met, exceeded, or did not meet faculty expectations as shown in the rubric, where an average of 2.5 for all criteria meets expectations and 3.5 exceeds expectations.

Though provision is made for individual grades to avoid free riding, members of a team normally receive the same grade. This practice encourages teamwork without reducing the motivation to work hard and perform with excellence. In a formal Awards Dinner, the top two teams receive plaques for First Place and Runner-Up.

The grading process is exhaustive and includes individual faculty evaluations of each of the sixteen criteria, on a five-point scale, before and during the presentations, and faculty grading meetings in the week following the presentations. The discussion of each group report and presentation may take between forty minutes and two hours per group, until there is consensus on the number to be assigned to each of the sixteen criteria. Each faculty member must provide the groups that he or she has supervised with detailed feedback memos. In fact, a major purpose of these grading meetings is to provide input for the preparation of these memos.

\section{Assessing Critical Thinking in the MCP experience}

Unlike the two previous measures, we are not measuring improvements over time; consequently, it is not possible to discern whether the program had or did not have an impact on students' critical thinking skills. For that we would need a baseline comparison equally comprehensive, and there is no such equivalent within the MBA program. However, by examining the students' MCP performance on those criteria most related to critical thinking skills (problem identification; the understanding of company strategy and its implications; the identification and evaluation of alternatives), it may be seen in Table 5 that students, on average, not only met but exceeded faculty expectations in two of the three.

We can see in Table 5 that the third criterion, understanding the company strategy and its implications, received the lowest average score of the eleven used to assess the consulting report. Problem identification is near the median, but certainly below the average. These results seem to confirm the findings from the pre- post-written case analysis with respect to the difficulty students seem to have in defining and framing problems correctly. However, since students did meet faculty expectations on the understanding of company strategy and exceeded expectations on prob- 
lem identification, the issue seems to be more one of relative comparison than one of absolute level.

Table 5: Average Scores, MCP Reports

\begin{tabular}{|l|l|}
\hline Criteria & $\mathbf{2 0 0 9 / 1 0}$ \\
\hline Executive summary & 3.75 \\
\hline Problem identification & 3.70 \\
\hline Company strategy and implications & 3.36 \\
\hline External analysis: environment, industry & 3.59 \\
\hline Internal analysis: organization, bus functions & 3.44 \\
\hline Evaluation of alternatives & 3.88 \\
\hline Recommendations: clear and implementable & 3.97 \\
\hline Action plan: what, when, who & 4.00 \\
\hline Financial viability & 3.54 \\
\hline Social / environmental sustainability issues & 4.56 \\
\hline Report quality: organization, coherence, etc. & 3.72 \\
\hline
\end{tabular}

In our discussion of the pre- post- written case analyses, it was concluded that the students' skills with respect to the analysis of alternatives had actually become weaker over the course of the program. But when looking at MCP results, students performed relatively well on this facet of critical thinking, exceeding expectations. During the MCP experience, students seldom have a set of pre-defined alternatives to evaluate and must generate them based on their analysis of the particular situation. The fact that they are indeed performing well could be explained by the emphasis placed by the MCP on offering the client a feasible solution, which in turns makes it a priority for the students. Hence, we find some support for the caveat advanced in the previous section that some of the results could be at least partially due to the different nature of the written case assignments.

Results in Table 6 are more consistent with the findings of the pre-post-case analysis with respect to the students' ability to communicate effectively, with the average scores exceeding expectations in all categories of MCP presentations. This is a dimension that by its very nature cannot be captured in standardized tests and only partially in written analyses, but that we nonetheless consider an integral part of critical thinking for action.

Table 6: Average Scores, MCP Presentations

\begin{tabular}{|l|l|}
\hline Criteria & $\mathbf{2 0 0 9 / 1 0}$ \\
\hline Logical order and sequencing; smooth transitions & 3.60 \\
\hline Quality of slides and other visual / audio effects & 3.75 \\
\hline Clear, coherent, and persuasive presentation & 3.70 \\
\hline Precise and correct responses to questions & 3.83 \\
\hline Effective use and distribution of time & 3.93 \\
\hline
\end{tabular}


Finally, it is worth noting that these results are obtained after coaching and feedback from MCP faculty advisors during the eight-week process and prior to the delivery of the final report. Even though interim reports are not graded, there is consensus among MCP faculty that there is a marked improvement in the quality of students' written work as a result of the feedback that they receive.

\section{Discussion and Concluding Remarks}

Critical thinking for action is an essential activity for managers that demands an array of very different skills and dispositions that go from problem recognition and framing, weighing evidence, reflecting upon one's own reasoning, developing counter-arguments and alternative hypothesis, to communicating decisions. Assessing these skills among MBA students is equally challenging, and demands multiple measures.

The application of standardize tests allowed us to established several facts. To begin with, the CCTS Test showed that the critical thinking skills of our incoming MBA students, most of whom have been educated in Latin-American universities, are lower than those of U.S. college graduates. By applying this same test at the end of the program, we found that students in our program improve their critical thinking skills during the MBA, narrowing or closing the gap with respect to their U.S. peers. The fact that the program did not have a significant impact on critical thinking dispositions could be construed as either a positive or a negative, given studies that showed declining dispositions in other programs. Though informative, these tests told us little about how to improve critical thinking skills and dispositions among our students.

When we compared written case analyses at the beginning and at the end of the program we found that the MBA seemed to improve students' capabilities to formulate action plans, a very important result within the context of critical thinking for action. However, we also found that the students' ability to identify and analyze problems appeared to deteriorate, a result which could be at least partially attributed to differences in the complexity of the cases and in the specificity of the instructions. This result suggested the hypothesis that students were not transferring critical thinking skills to unstructured situations outside the realm of the managerial decisions course.

Alternatively, following Kahneman (2011), it may be that since critical thinking is a set of higher order thinking skills, students will exercise only those that the situation specifically calls for, due to either an explicit set of rules as provided in the MD course, or a specific set of incentives as offered by the MCP experience. When these rules and incentives are absent, students trust their more basic intuitive thinking processes. This intuitiveness, as opposed to active truth-seeking, could explain the low level of critical thinking dispositions. Or, it could be precisely why we are not having an impact on dispositions (as we are having in skills) as a result of the program: dispositions may be more hard-wired and related to how the brain actually functions. But attempting to explore such a claim is beyond the scope of this paper.

However, we further explore this issue by analyzing student performance on the capstone MCP experience, finding that the absence of an explicit definition does not necessarily imply a lack of intuitive understanding: students struggled but frequently succeeded in correctly defining problems when they faced situations in which the problem could not be taken for granted or assumed away.

This multi-measure approach enabled us to not only identify areas requiring improvement in critical thinking skills but also to take action in making those improvements. To address weaknesses in the application of explicit frameworks, the school introduced a second managerial decisions course at the end of the first year. This ten-session course was designed to reinforce the analytical framework in the context of complex managerial decision cases. 
The course-embedded MCP measure added yet another important change in the MBA program that should lead to improvements in critical thinking skills. The grading and assessment of student learning, which may produce different results (grading curve versus absolute standards) but follows the same process, opens informing pathways among managerial decisions professors and professors from the different functional areas, who are also MCP advisors, helping ensure that the decision framework is applied in case discussions across disciplines. A schematic description of this informing network is depicted in Figure 5.

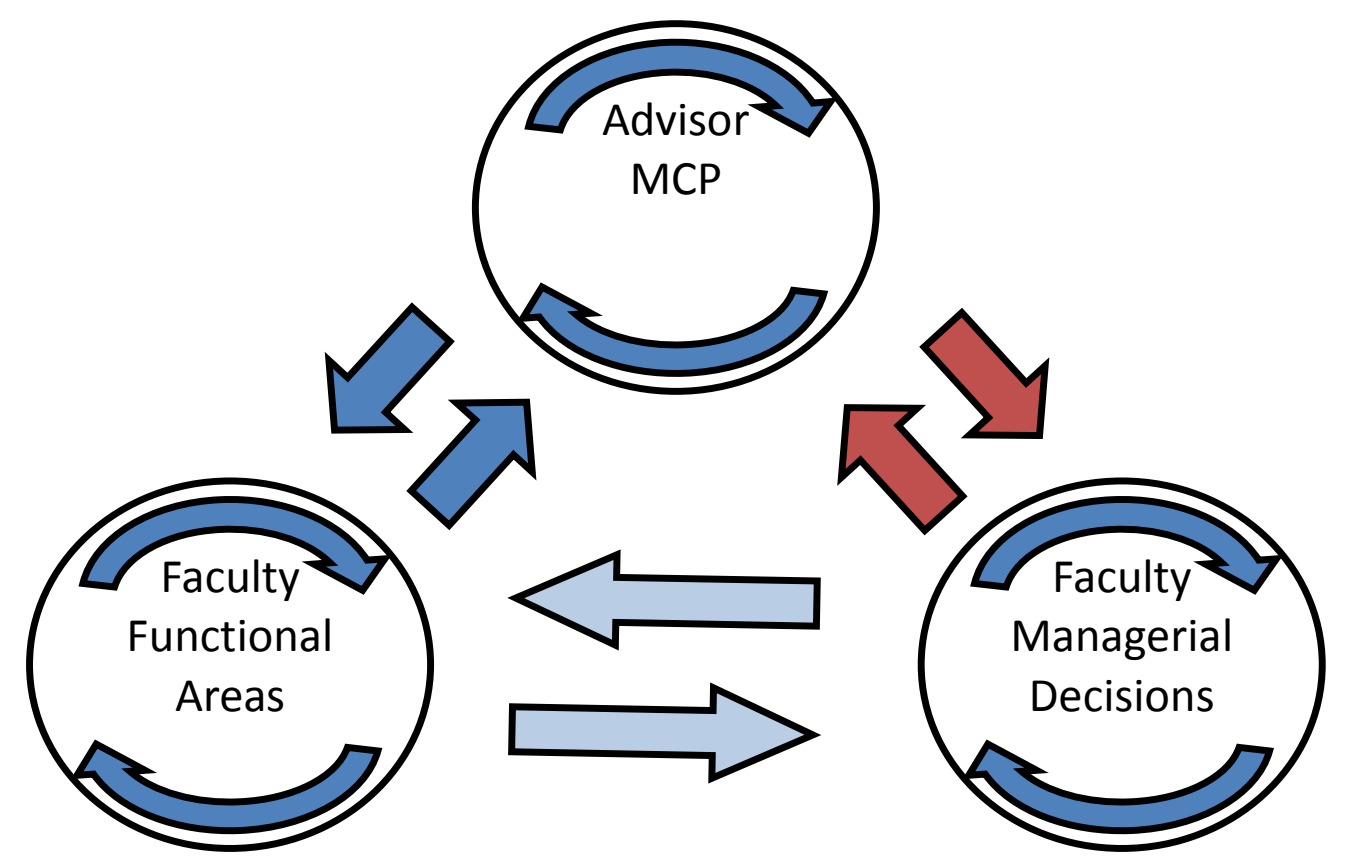

Figure 5: Informing Network

The arrows in dark blue represent the traditional informing flows between and across different groups of faculty. The arrows in light blue represent the new informing patterns that arose between the faculty teaching in functional areas and the Management Decisions faculty. By highlighting the finding that students were not applying the analytic framework outside the management decisions courses, it became clear that the framework must be applied and reinforced in the functional area courses as well. A similar pattern of poor informing flows was evident between MCP advisors and the Management Decisions faculty (red arrows). Both groups needed to reflect upon what they were doing and make sure that they were being consistent in their approach to critical thinking.

It is important to note that we were only able to consider the above issues because we applied a multi-measures approach to assessing the impact of student-centered teaching / learning methodologies in improving critical thinking skills and the disposition to apply those skills among our students. If anything is clear from our experience, it is that the intrinsic complexity of the critical thinking process requires the use of more than one appraisal instrument if our objective is to improve student skills. For this reason we propose using multiple measures to ensure against the bias of a single instrument, but also to enable going beyond measurement and taking corrective action. The dramatic improvements in inductive and inferential skills among our students masked weaknesses in problem framing and definition, revealed by the pre- post- written case analyses. The greater skills in problem identification demonstrated by students in the MCP capstone experience suggests that context influences the application of conceptual frameworks, and that an intuitive process may have been at work when students were confronted with solving the more complex post- case. When confronting a real world situation, students could not assume away the 
problem and had to draw upon their inductive and inferential skills to define it, which brings to mind a comment that we have heard from more than one student: "it was not until the MCP experience that I fully understood the value of the case method."

A final lesson is that whatever assessment methods are used, the results of the assessment must be broadly shared through informing patterns among different groups of faculty (and with other groups), as it is this informing process that leads to program improvements. In the four years since the MCP assessment was introduced, some twenty-five recommendations for improvement of the MBA program have been made by MCP faculty, and all but a few have been implemented. This could not have been accomplished with a single assessment instrument. The most important and encouraging lesson from our experience, however, is that it is indeed possible to have a positive impact on the critical thinking for action of MBA students through the use of the case method.

\section{References}

Arons, A. (1985). Critical thinking baccalaureate curriculum. Liberal Education, 1(2), 142.

Bauman, Y., \& E. Rose (2009). Why are economics students more selfish than the rest? IZA Discussion Paper.

Datar, S., Garvin, D., \& Cullen, P., (2010). Rethinking the MBA: Education at a crossroads. Boston, MA: Harvard Business Press.

Ennis, R. H. (2002). Goals for a critical thinking curriculum and its assessment. In Costa, A. L., Editor (Ed.), Developing minds (3rd Edition). Alexandria, VA: ASCD. Pp. 44-46.

Facione, P. (1990). The Delphi Report - Executive summary. Retrieved October 19, 2012 from: http://austhink.com/critical/pages/definitions.html

Fisher, A., \& Scriven, M. (1997). Critical thinking: Its definition and assessment. Point Reyes, CA: Edgepress and Norwich, UK Centre for Research in Critical Thinking, University of East Anglia.

Frank, B., \& Schulze, G. G. (2000). Does economics make citizens corrupt? Journal of Economic Behavior \& Organization, 43(1), 101-113.

Garvey, J., \& Buckley, P. (2011). Using technology to encourage critical thinking and optimal decision making in risk management education. Risk Management and Insurance Review, 14(2), 299-309.

Ickis, J., \& Barahona, J. C., \& Castro, R., \& Leguizamón, F., \& Kilian, B., \& Metzger, M. (2009). Report on the Results, First Program Assessment. Internal memorandum, INCAE Business School.

Kahneman, D. (2011). Thinking, fast and slow. Great Britain: Allen Lane.

McLellan, J. (2012). Assessing the critical thinking abilities of United Arab Emirates University business students. Learning and Teaching in Higher Education: Gulf Perspectives. Retrieved October 19, 2012 from: http://ssrn.com/asbtract=1932038

Nickerson, R. S., Perkins, D. N., \& Smith, E. E. (1985). The teaching of thinking. Hillsdale, NJ: Lawrence Erlbaum Associates.

Paul, R. (1990). Critical thinking. Rohnert Park: Sonoma State University.

Paul, R., \& Elder, L. (2005). Critical thinking: Tools for taking charge of your learning and your life. Upper Saddle River, NJ: Pearson/Prentice Hall.

Pomonis, G., \& Siriopoulos, C. (2009). Combining lectures and case studies in teaching financial management to MBA students: A quantile regression exploration of the impact on learning styles and critical thinking skills. Retrieved on May 31, 2012, from http://papers.ssrn.com/sol3/papers.cfm?abstract id $=1539140$

Schoenberg, B. (2007). Critical thinking in business. Chesterfield, MO: Heuristic Books. 
Williams, L., \& Lhama, M. (2009). Online discussion, student engagement, and critical thinking. Retrieved on May 31, 2012, from http://papers.ssrn.com/sol3/papers.cfm?abstract id=1448970

\section{Biographies}

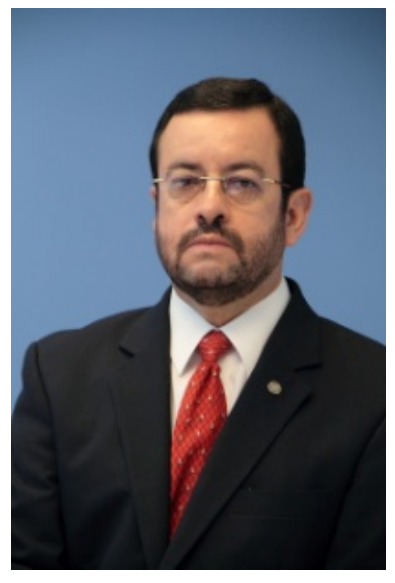

Dr. Luis Noel Alfaro Gramajo is a scholar, consultant, and entrepreneur born in Guatemala. He is Professor at INCAE Business School. He teaches Master level courses in the areas of Finance and Managerial Control, Management of Microfinance and Development Financial Institutions, Entrepreneurship and New Businesses, and Management Consulting Practice (MCP). As Founder and Academic Director of MCP, during the last sixteen years, he has had the opportunity of supporting more than two hundred companies all over the American Continent (among them, BAYER CORPORATION, in U.S.A.; and CARRIER CORPORATION, Pfizer, and "Grupo Gigante" in Mexico) in the solution of strategic and managerial problems.

Professor Alfaro obtained his doctoral degree (Ph.D. in Agricultural Economics and Rural Sociology) in The Ohio State University, Columbus, Ohio, U.S.A., with specialization in the areas of Finance for Development, Institutional Analysis, and Economic and Social Development. He also obtained a Masters of Sciences in Agricultural Economics with specialization in Rural Financial Markets from The Ohio State University. Previously, he earned an M.B.A. and a Postgraduate degree in Functional Management (graduated with honors) at INCAE Business School. He did his doctoral studies as scholar of the World Bank Graduate Scholarship Program. In 2010, Professor Alfaro was selected by the College of Food, Agricultural and Environmental Sciences Alumni Society Board of Directors at The Ohio State University to receive the 2010 International Alumni Award in recognition of his significant contribution to agriculture in his region and the world. Also, in 2011, the BANRURAL Financial Group in Guatemala selected Professor Alfaro to receive $\boldsymbol{E} \boldsymbol{l}$ Sol de Banrural (The Banrural Sun) in recognition "of his invaluable and constant example of positive attitude and disposition to build in Guatemala a country of opportunities to all the sectors of the population without any exclusion".

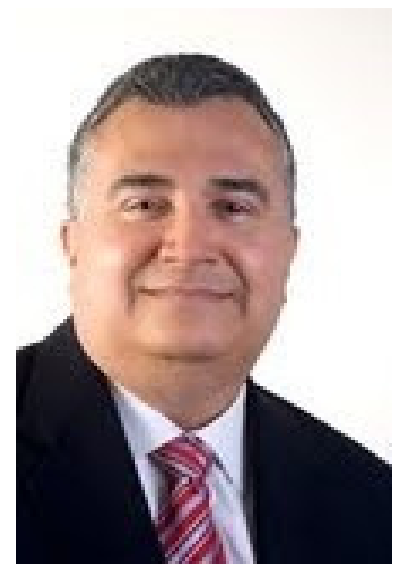

Felipe Pérez Pineda holds a $\mathrm{PhD}$ in Agricultural Economics from Purdue University, where his areas of specialization were Natural Resource Economics and Business Strategy. He graduated Master of Business Administration from INCAE with concentration in Banking and Finance for Development. Professor Pérez is also agronomist specialized in Irrigation of the Autonomous University of Chapingo, Mexico. Faculty member of INCAE with the rank of Full Professor, headed the Agro-Industry Program of the Institute for several years. He also directed the Export-Nicaragua program at the Center for Entrepreneurship at INCAE. His experience as a teacher in executive programs has been backed by several years of practice in different countries before and as a member of the teaching faculty of INCAE. Professor Pérez is also an international consultant and advisor to several companies in Latin America.

Professor Perez teaches courses in Sustainability Management, Introduction to Financial Simulation, Sustainable Development and Corporate Social Responsibility and Quantitative Methods in INCAE's Masters Programs in Nicaragua and Costa Rica. It is also the academic 
coordinator of the areas of Quantitative Methods and Sustainable Development at INCAE. He is the author and supervisor of numerous cases and teaching notes on various subjects of business administration. Professor Perez has participated in several international congresses and conferences and has presented his research results in these forums. Post actively in business magazines and newspapers of the region. His general areas of research interest are Corporate Social Responsibility and Competitiveness, Sustainability and Agribusiness, Business Innovation and Sustainability in the base of the pyramid.

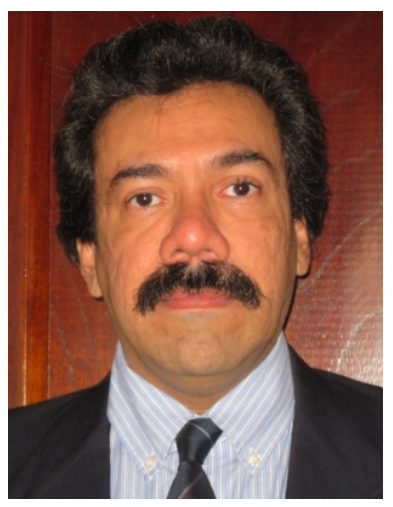

Carlos Quintanilla is an Associate Professor of Economics and Statistics at INCAE Business School. He teaches Master level courses in the areas of Economics, Statistics and Data Mining. He obtained his Ph. D. in Economics from the University of Michigan in 2000. He also holds Master's Degrees in Economics and Statistics from the same university. His professional interests are Data Mining, Statistics, Investment \& Personal Finance. He has worked as a Visiting Professor for the Rotterdam School of Management in the Netherlands. Recent publications of Prof. Quintanilla are "Estimating willingness-to-pay and financial feasibility in small water projects in El Salvador" with Felipe Perez-Pineda (Journal of Business Research, October 2013), "Country Effects on Profitability: a Multilevel Approach using a Sample of Central American Firms" with Niels Ketelhohn (Journal of Business Research, December 2012).

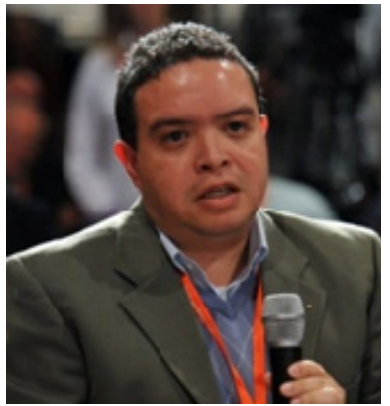

Luis J. Sanz is an expert in financial problems of Latin American companies, with more than 70 teaching cases written or supervised about companies with operations in Latin America, and has received international awards for his research. Venezuelan, and married to a Costa Rican, Professor Sanz has lived in five countries and has taught in Latin America, United States and Spain. Full Professor of Finance at INCAE Business School in Central America, Luis combines his skills in research and teaching to inspire practitioners to create value, while his multiple trips and interest in contemporary literature allow him to do so with awareness of its cultural context.

His experiences as a consultant, angel investor, investment committee member on a social venture capital fund and external board member complement his academic perspective with a current and practical approach. Professor Sanz holds a Ph.D. in economics from the University of Pennsylvania, and has served at INCAE Business School as Associate Dean of Master Programs and Director of the Entrepreneurship Center. He is also the Strachan Professor on Philanthropy and Social Investment, President of Business Association of Latin American Studies, and fellow STARS, CALI (Central American Leadership Initiative) and AGLN (Aspen Global Leadership Initiative). He keeps his personal blog on www.luisjsanz.com and Twitter @1uisjsanz. Direct contact: Luis.Sanz@incae.edu. 


\section{Appendix: Capstone Course Rubric}

\begin{tabular}{|c|c|c|c|c|c|c|c|c|}
\hline & $\underline{\mathbf{R}}$ & ort & & Award & High Pass & Pass & Fail & N. R. \\
\hline & 1 & Executiv & Summary & $\begin{array}{l}\text { Can stand } \\
\text { alone, correctly } \\
\text { summarizing } \\
\text { content of } \\
\text { report clearly } \\
\text { and concisely, } \\
\text { in way that } \\
\text { motivates } \\
\text { reader }\end{array}$ & $\begin{array}{l}\text { Can stand } \\
\text { alone, is } \\
\text { reasonably } \\
\text { clear and } \\
\text { concise, } \\
\text { contains few } \\
\text { errors, but } \\
\text { does not } \\
\text { motivate } \\
\text { reader }\end{array}$ & $\begin{array}{l}\text { Correctly } \\
\text { describes major } \\
\text { parts of Report } \\
\text { but missing } \\
\text { substantive } \\
\text { parts so cannot } \\
\text { stand alone; } \\
\text { contains errors }\end{array}$ & $\begin{array}{l}\text { Does not } \\
\text { adequately } \\
\text { or correctly } \\
\text { summarize } \\
\text { the content } \\
\text { of the Re- } \\
\text { port, con- } \\
\text { tains many } \\
\text { errors }\end{array}$ & \\
\hline & 2 & $\begin{array}{l}\text { Identific } \\
\text { lem, op }\end{array}$ & $\begin{array}{l}\text { ion of the prob- } \\
\text { rtunity or need }\end{array}$ & $\begin{array}{l}\text { Demonstrates } \\
\text { clear under- } \\
\text { standing of the } \\
\text { situation in } \\
\text { convincing and } \\
\text { competing way; } \\
\text { shows causal } \\
\text { relationships } \\
\text { using evidence }\end{array}$ & $\begin{array}{l}\text { Demon- } \\
\text { strates clear } \\
\text { understand- } \\
\text { ing of the } \\
\text { situation and } \\
\text { its causes, } \\
\text { with good } \\
\text { use of evi- } \\
\text { dence and } \\
\text { mastery of } \\
\text { decision }\end{array}$ & $\begin{array}{l}\text { States what the } \\
\text { problem, } \\
\text { opportunity or } \\
\text { need is but } \\
\text { does not con- } \\
\text { vincingly ex- } \\
\text { plain why it is a } \\
\text { problem }\end{array}$ & $\begin{array}{l}\text { Does not } \\
\text { adequately } \\
\text { or correctly } \\
\text { identify the } \\
\text { problem, } \\
\text { opportunity, } \\
\text { or need }\end{array}$ & $\begin{array}{l}\text { when so } \\
\text { obvious as } \\
\text { to be } \\
\text { irrelevant }\end{array}$ \\
\hline & 3 & $\begin{array}{l}\text { Strategy } \\
\text { tion }\end{array}$ & the organiza- & $\begin{array}{l}\text { Demonstrates } \\
\text { clear under- } \\
\text { standing of the } \\
\text { strategy using } \\
\text { evidence, } \\
\text { questions its } \\
\text { underlying } \\
\text { assumptions } \\
\text { and uses strat- } \\
\text { egy concepts to } \\
\text { evaluate it }\end{array}$ & $\begin{array}{l}\text { Demon- } \\
\text { strates clear } \\
\text { understand- } \\
\text { ing of strat- } \\
\text { egy with } \\
\text { good use of } \\
\text { evidence and } \\
\text { mastery of } \\
\text { strategy } \\
\text { concepts }\end{array}$ & $\begin{array}{l}\text { States in gener- } \\
\text { ally correct } \\
\text { terms what the } \\
\text { strategy is and } \\
\text { conveys satis- } \\
\text { factory under- } \\
\text { standing of } \\
\text { strategy con- } \\
\text { cepts }\end{array}$ & $\begin{array}{l}\text { Does not } \\
\text { correctly } \\
\text { identify the } \\
\text { strategy and } \\
\text { / or demon- } \\
\text { strates lack } \\
\text { of under- } \\
\text { standing of } \\
\text { strategy } \\
\text { concepts }\end{array}$ & \\
\hline 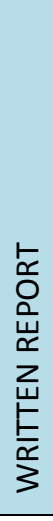 & $\frac{\frac{n}{n}}{\frac{\pi}{\sqrt{n}}}$ & $\begin{array}{l}4 \text { Ex- } \\
\text { ternal }\end{array}$ & $\begin{array}{l}\text { Pol/Ec/Soc/Tec } \\
\text { / } \\
\text { Ecol/Legal } \\
\text { environment, } \\
\text { industry, mar- } \\
\text { ket }\end{array}$ & $\begin{array}{l}\text { Analyzes all } \\
\text { relevant exter- } \\
\text { nal aspects, } \\
\text { correctly using } \\
\text { appropriate } \\
\text { frameworks } \\
\text { and research } \\
\text { methods, and } \\
\text { presents clear } \\
\text { and support- } \\
\text { able conclu- } \\
\text { sions }\end{array}$ & $\begin{array}{l}\text { Analyzes all } \\
\text { relevant } \\
\text { external } \\
\text { aspects of } \\
\text { external } \\
\text { environment, } \\
\text { correctly } \\
\text { using appro- } \\
\text { priate } \\
\text { frameworks } \\
\text { and research } \\
\text { methods }\end{array}$ & $\begin{array}{l}\text { Analyzes most } \\
\text { relevant exter- } \\
\text { nal aspects of } \\
\text { external envi- } \\
\text { ronment, } \\
\text { demonstrating } \\
\text { satisfactory } \\
\text { knowledge and } \\
\text { use of appro- } \\
\text { priate frame- } \\
\text { works and } \\
\text { research meth- } \\
\text { ods }\end{array}$ & $\begin{array}{l}\text { Does not } \\
\text { demonstrate } \\
\text { satisfactory } \\
\text { knowledge } \\
\text { and / or use } \\
\text { of appropri- } \\
\text { ate frame- } \\
\text { works and } \\
\text { research } \\
\text { methods for } \\
\text { analysis of } \\
\text { the external } \\
\text { environ- } \\
\text { ment, indus- } \\
\text { try or market }\end{array}$ & $\begin{array}{l}\text { when } \\
\text { project } \\
\text { focus is on } \\
\text { external } \\
\text { issues }\end{array}$ \\
\hline
\end{tabular}




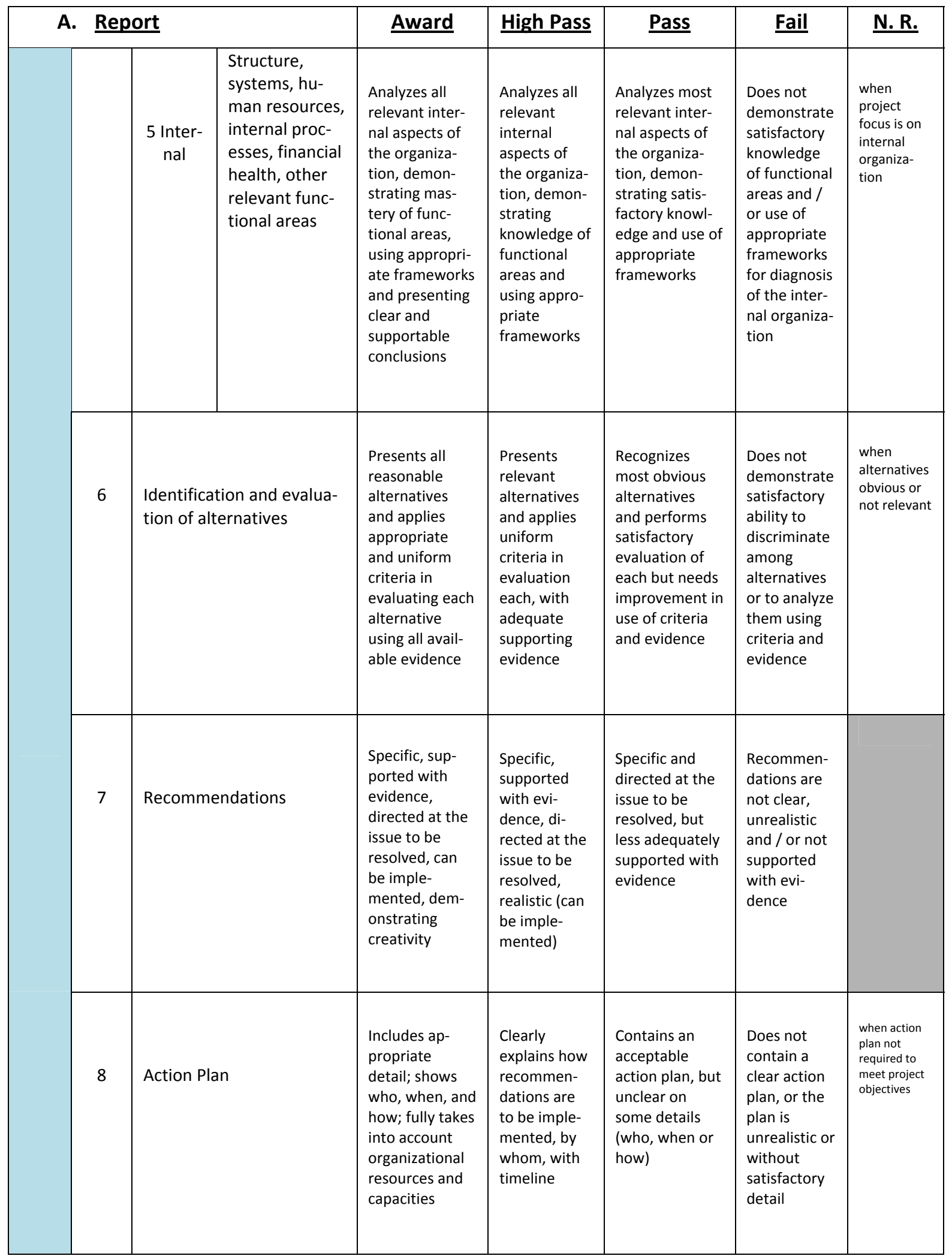




\begin{tabular}{|c|c|c|c|c|c|c|}
\hline \multicolumn{2}{|c|}{ A. Report } & Award & High Pass & $\underline{\text { Pass }}$ & Fail & N. R. \\
\hline 9 & Financial viability & $\begin{array}{l}\text { Correctly shos } \\
\text { financial impact } \\
\text { of recommen- } \\
\text { dations and } \\
\text { action plan in } \\
\text { detail, using } \\
\text { appropriate } \\
\text { analytic tools } \\
\text { and measures } \\
\text { (NPV, Monte } \\
\text { Carlo, etc.) }\end{array}$ & $\begin{array}{l}\text { Correctly } \\
\text { shows finan- } \\
\text { cial impact or } \\
\text { recommen- } \\
\text { dations and } \\
\text { action plan in } \\
\text { detail, max- } \\
\text { ing effective } \\
\text { use of ap- } \\
\text { propriate } \\
\text { analysis tools } \\
\text { and meas- } \\
\text { ures }\end{array}$ & $\begin{array}{l}\text { Shows financial } \\
\text { impact of } \\
\text { recommenda- } \\
\text { tions with } \\
\text { satisfactory use } \\
\text { of analytic tools } \\
\text { and measures, } \\
\text { but in less } \\
\text { detail or with } \\
\text { some minor } \\
\text { errors }\end{array}$ & $\begin{array}{l}\text { Either does } \\
\text { not shows } \\
\text { financial } \\
\text { impact of } \\
\text { recommen- } \\
\text { dations or } \\
\text { does so with } \\
\text { substantial } \\
\text { errors in the } \\
\text { use of ana- } \\
\text { lytic tools } \\
\text { and meas- } \\
\text { ures }\end{array}$ & $\begin{array}{l}\text { When } \\
\text { demonstra- } \\
\text { tion of } \\
\text { financial } \\
\text { viability not } \\
\text { required }\end{array}$ \\
\hline 10 & $\begin{array}{l}\text { Social / environmental } \\
\text { sustainability }\end{array}$ & $\begin{array}{l}\text { Recommenda- } \\
\text { tions include } \\
\text { sustainability } \\
\text { criteria, cor- } \\
\text { rectly and with } \\
\text { a high level of } \\
\text { creativity }\end{array}$ & $\begin{array}{l}\text { Recommen- } \\
\text { dations } \\
\text { include } \\
\text { sustainability } \\
\text { criteria, } \\
\text { correctly and } \\
\text { in detail }\end{array}$ & $\begin{array}{l}\text { Recommenda- } \\
\text { tions satisfacto- } \\
\text { rily include } \\
\text { sustainability } \\
\text { criteria }\end{array}$ & $\begin{array}{l}\text { Recommen- } \\
\text { dations and } \\
\text { sustainability } \\
\text { criteria } \\
\text { where these } \\
\text { are required, } \\
\text { or apply the } \\
\text { criteria } \\
\text { incorrectly } \\
\text { H100 }\end{array}$ & $\begin{array}{l}\text { when } \\
\text { directly } \\
\text { related to } \\
\text { project }\end{array}$ \\
\hline 11 & Overall quality of Report & $\begin{array}{l}\text { Adherence to } \\
\text { guidelines; } \\
\text { logical organi- } \\
\text { zation, clarity in } \\
\text { expression of } \\
\text { ideas, absences } \\
\text { of grammatical } \\
\text { or typographi- } \\
\text { cal errors, } \\
\text { pages num- } \\
\text { bered, indices } \\
\text { included }\end{array}$ & $\begin{array}{l}\text { Adherence to } \\
\text { guidelines; } \\
\text { logical or- } \\
\text { ganization, } \\
\text { clarity in } \\
\text { expression of } \\
\text { ideas, few } \\
\text { grammatical } \\
\text { or typo- } \\
\text { graphical } \\
\text { errors }\end{array}$ & $\begin{array}{l}\text { Adherence to } \\
\text { guidelines; } \\
\text { reasonably } \\
\text { contents, } \\
\text { admissible } \\
\text { number of } \\
\text { grammatical or } \\
\text { typographical } \\
\text { errors }\end{array}$ & $\begin{array}{l}\text { Does not } \\
\text { adhere to } \\
\text { guidelines; } \\
\text { incoherent, } \\
\text { or inadmis- } \\
\text { sible number } \\
\text { of gram- } \\
\text { matical or } \\
\text { typographi- } \\
\text { cal errors }\end{array}$ & \\
\hline
\end{tabular}




\begin{tabular}{|c|c|c|c|c|c|c|c|}
\hline & I & resentation & Award & High Pass & Pass & Fail & N. \\
\hline & 1 & $\begin{array}{l}\text { Logical order and } \\
\text { sequencing }\end{array}$ & $\begin{array}{l}\text { Presentation flows } \\
\text { logically from one } \\
\text { section to another } \\
\text { and sequencing } \\
\text { holds audience } \\
\text { attention }\end{array}$ & $\begin{array}{l}\text { Presentation flows } \\
\text { logically from on } \\
\text { section to another }\end{array}$ & $\begin{array}{l}\text { Presentation } \\
\text { flows in rea- } \\
\text { sonably logical } \\
\text { sequence but } \\
\text { with little transi- } \\
\text { tion or flow from } \\
\text { one section to } \\
\text { another }\end{array}$ & $\begin{array}{l}\text { Presentation is } \\
\text { disjointed, does } \\
\text { not flow in logical } \\
\text { fashion, appear to } \\
\text { jump around } \\
\text { among time } \\
\text { periods and / or } \\
\text { topics }\end{array}$ & \\
\hline Z & 2 & $\begin{array}{l}\text { Audio-visual qual- } \\
\text { ity }\end{array}$ & $\begin{array}{l}\text { The slides / videos } \\
\text { not only facilitate } \\
\text { understanding of the } \\
\text { presentation but are } \\
\text { creative, adding to } \\
\text { the audience's } \\
\text { interest }\end{array}$ & $\begin{array}{l}\text { The slides / videos } \\
\text { are clear, simple, } \\
\text { and facilitate } \\
\text { understanding of } \\
\text { the presentation }\end{array}$ & $\begin{array}{l}\text { The slides con- } \\
\text { tain few errors } \\
\text { but are over- } \\
\text { loaded with data } \\
\text { or otherwise do } \\
\text { not facilitate } \\
\text { understanding of } \\
\text { presentation }\end{array}$ & $\begin{array}{l}\text { The slides are } \\
\text { unclear or contain } \\
\text { an unacceptable } \\
\text { number of errors } \\
\text { and / or confuse } \\
\text { the audience }\end{array}$ & \\
\hline 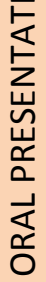 & 3 & Oral presentation & $\begin{array}{l}\text { Clear and convincing, } \\
\text { speakers engage } \\
\text { audience, are com- } \\
\text { pletely familiar with } \\
\text { the data and do not } \\
\text { need to read the } \\
\text { slides }\end{array}$ & $\begin{array}{l}\text { Clear and convinc- } \\
\text { ing, speakers are } \\
\text { completely famil- } \\
\text { iar with the data } \\
\text { and only rarely } \\
\text { glance at the } \\
\text { slides }\end{array}$ & $\begin{array}{l}\text { Reasonably clear } \\
\text { presentation, } \\
\text { speakers have } \\
\text { satisfactory } \\
\text { knowledge of } \\
\text { data but must } \\
\text { frequently read } \\
\text { from slides }\end{array}$ & $\begin{array}{l}\text { There is lack of } \\
\text { clarity, poor } \\
\text { preparation and / } \\
\text { or unfamiliarity } \\
\text { with the data } \\
\text { being presented }\end{array}$ & \\
\hline & 4 & $\begin{array}{l}\text { Responses to } \\
\text { questions }\end{array}$ & $\begin{array}{l}\text { Responses to all Q's } \\
\text { are clear, well docu- } \\
\text { mented, not over } \\
\text { extended and well } \\
\text { distributed among } \\
\text { group members }\end{array}$ & $\begin{array}{l}\text { Responses to } \\
\text { almost all Q's are } \\
\text { clear and well } \\
\text { documented, with } \\
\text { most group mem- } \\
\text { bers participating }\end{array}$ & $\begin{array}{l}\text { Responses to } \\
\text { most Q's are } \\
\text { satisfactory but } \\
\text { there is some } \\
\text { lack of clarity } \\
\text { and / or domi- } \\
\text { nance by } 1 \text { of } 2 \\
\text { groups members }\end{array}$ & $\begin{array}{l}\text { Responses to } \\
\text { many Q's are } \\
\text { unclear and / or } \\
\text { unsupported by } \\
\text { data }\end{array}$ & \\
\hline & 5 & Use of time & $\begin{array}{l}\text { Time is optimally } \\
\text { distributed among } \\
\text { the various topics } \\
\text { presented }\end{array}$ & $\begin{array}{l}\text { Time is well } \\
\text { distributed among } \\
\text { the various topics } \\
\text { presented }\end{array}$ & $\begin{array}{l}\text { The group man- } \\
\text { ages to cover all } \\
\text { topics but time } \\
\text { not well distrib- } \\
\text { uted }\end{array}$ & $\begin{array}{l}\text { The group does } \\
\text { not comer all } \\
\text { topics adequately, } \\
\text { needs overtime }\end{array}$ & \\
\hline & 1 & $\begin{array}{l}\text { Effectiveness in } \\
\text { planning }\end{array}$ & & & & & \\
\hline 乩 & 2 & $\begin{array}{l}\text { Ability to obtain } \\
\text { information }\end{array}$ & & & & & \\
\hline & 3 & $\begin{array}{l}\text { Relation with the } \\
\text { client }\end{array}$ & & & & & \\
\hline
\end{tabular}

